doi:10.4149/neo_2016_401

\title{
Protein synthesis inhibitors of natural origin for CML therapy: semisynthetic homoharringtonine (Omacetaxine mepesuccinate)
}

\section{Minireview}

L. NOVOTNY ${ }^{1}$, N. F. AL-TANNAK ${ }^{1}$, L. HUNAKOVA ${ }^{2, *}$

${ }^{1}$ Department of Pharmaceutical Chemistry, Faculty of Pharmacy, Kuwait University, 24923 Safat, 13110 Kuwait; ${ }^{2}$ Cancer Research Institute BMC SAS, Vlarska 7, 83391 Bratislava, Slovak Republic

*Correspondence: exonhun@savba.sk

Received December 17, 2015 / Accepted February 17, 2016

\begin{abstract}
Omacetaxine mepesuccinate is a drug approved in 2014 by FDA for the use in CML therapy in patients resistant to at least two thymidine kinase inhibitors (TKIs). It possesses unique mechanism of anticancer activity that is principally different from mechanism of activity of TKIs. Omacetaxine mepesuccinate inhibits protein translation through prevention of the initial elongation step of protein synthesis and its use benefits CML patients possessing the $B C R-A B L$ oncogene. Because of the superior activity of Omacetaxine in patients who became resistant to therapy with TKIs, FDA decided on the accelerated approval of this drug taking its consideration not only its activity as such but also a favorable benefit-to-risk profile in patients included into clinical studies.
\end{abstract}

Key words: Omacetaxine mepesuccinate, homoharringtonine, analytical determination, anti-cancer properties, protein synthesis inhibition, CML

\section{Harringtonine and homoharringtonine as natural compounds}

Harringtonine (NSC 124147; molecular weight 531.59 D) and homoharringtonine (NSC 141633; molecular weight 545.62 D) are two alkaloids of rather complex structure. As alkaloids, they contain a nitrogen atom (see Figure 1). They are also classified as norditerpenes. This indicates the biochemical way of their synthesis in coniferous plants and partially the relationship of their chemical structure to diterpenes containing four isoprene units.

In nature, these two substances are being present in coniferous trees of Cephalotaxus genus belonging to Cephalotaxaceae family (Plum Yew or Cowtail Pine) includes 72 species according to the data in the Plant List 2013 [1]. C. fortunei, C. griffithii, C. hainanensis, C. harringtonia, C. koreana, C. lanceolata, C. latifolia, C. mannii, C. oliveri, C. sinensis and C. wilsoniana are the most known species. The plants are endemic to eastern Asia [1].

\section{Analytical determination of harringtonine and homoharringtonine}

Chemical determination of harringtonine and homoharringtonine in preclinical and clinical studies is usually performed using modern instrumental analytical methods, namely chromatography, mainly due to the complex structure of this molecule and because chemical properties of homoharringtonine and related compounds were not studied extensively before the discovery of its benefits in cancer patients. Mass spectrometry is a method of choice for detecting these alkaloids as analytes in analyzed samples of clinical or non-clinical origin. These methods were essential in developing homoharringtonine into the approved drug. The short overview of the methods used for analysis of both compounds (homoharringtonine and harringtonine) is in Table 1 [2-17] - the references are in the order from the most new to the oldest. The tremendous development in the area of instrumental analysis is obvious from the table when 


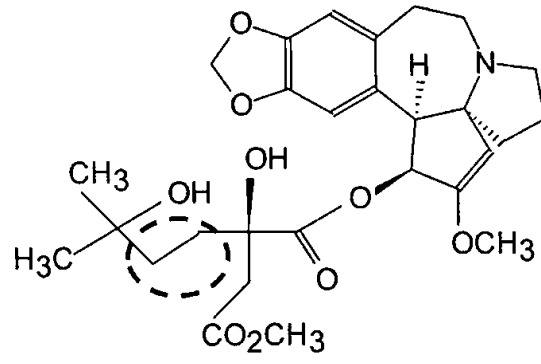

A

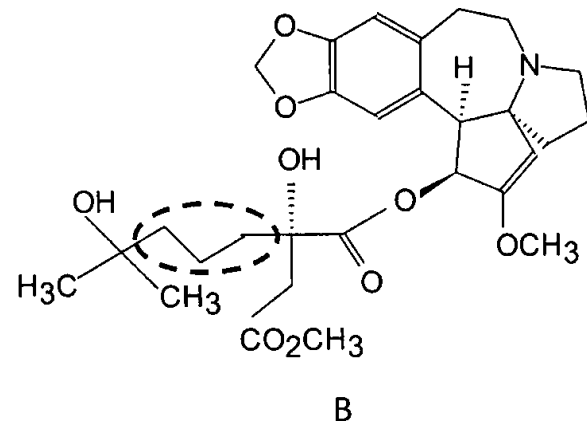

C

Figure 1. Chemical structures of $A$ ) harringtonine $\left.\left(\mathrm{C}_{28} \mathrm{H}_{37} \mathrm{NO}_{9}\right), \mathrm{B}\right)$ homoharringtonine (Ceflatonin, Omacetaxine mepesuccinate, Synribo; $\left.\mathrm{C}_{29} \mathrm{H}_{39} \mathrm{NO}_{9}\right)$ and $\mathrm{C}$ ) cephalotaxine. The marked areas in formulas $\mathrm{A}$ and $\mathrm{B}$ indicate the difference in harringtonine and homoharringtonine chemical structures.

simple TLC (thin layer chromatography) was used [14] to application of sophisticated MS/MS mass spectrometry/mass spectrometry) methods [3] and microemulsion electrokinetic chromatography coupled with field-amplified sample injection [2]. HPLC (high-pressure liquid chromatography) is obviously a relatively simple and reliable method of analysis of harringtonine and homoharringtonine $[4-8,10-12,16]$. So are the counter-current chromatography [9] and originally used gas chromatography [17].

The use of MS/MS detection in its current state of art is advantageous as it allows direct detection and determination of the original drug and also of its metabolites, mainly the product of hydrolysis of the ester bond by various esterases [18] resulting in the formation of 4'-demethylharringtonine (also called homoharringtonine acid) [19]. The mentioned instrumental methods were used for harringtonine/Omacetaxine mepesuccinate determination during its preclinical development and clinical applications where omacetaxine mepesuccinate was determined in complex biological samples originating from patients. All of these methods are suitable for routine determination of homoharringtonine and harringtonine and provide clinicians with invaluable therapy-related information.

\section{Omacetaxine mepesuccinate}

To avoid any confusion, it is important to clarify that homoharringtonine is an alkaloid of a natural origin present in trees of Cephalotaxus genus. However, after discovering its strong anticancer activity, it was clear that these trees can only serve as a source for limited amount of homoharringtonine. The semisynthetic homoharringtonine that is for some reason of higher purity and stronger myelosuppression [20] is distinguished from the homoharringtonine from natural sources and is known and commercially available as Omacetaxine mepesuccinate.

Various syntheses of homoharringtonine and related harringtonine were attempted and reported in scientific literature. The first synthesis of harringtonine and its derivative by partial esterification of cephalotaxine (NSC 128487; 245454 and
245455; Figure 1) was reported in 1982 [21]. The semi-synthesis of enantiopure homoharringtonine via anhydrohomoharringtonine was reported in 1999 [22]. This synthesis was based on a direct esterification of cephalotaxine by the activated substituted tetrahydropyrancarboxilic acid (that was entered into synthesis in the form of methyl ester). Selective ring opening of the resulting anhydrohomoharringtonine resulted in enantiopure homoharringtonine (Figure 2) [22].

Reasons for semi-synthetic approach in chemical preparation is based on complexity of harringtonine chemical structure and on a relatively high availability of the natural alkaloid cephalotaxine in Cephalotaxus conifers. Additionally, cephalotaxine esterification used in homoharringtonine synthesis and resulting in an ester - homoharringtonine is based only on a few synthetic and purification steps/procedures. The semi-synthetic homoharringtonine in well known as omacetaxine mepesuccinate.

Various syntheses of cephalotaxine were reported as well [i.e. 23, 24], however they did not reach practical application. Moreover, chemical modification/esterification of cephalotaxine probably yields a substance that is superior in purity to homoharringtonine obtained from natural source, as it was observed that omacetaxine has been more myelosuppressive than homoharringtonine [20].

\section{Mechanism of activity}

Homoharringtonine (or omacetaxine) mechanism of action is based on inhibition of protein translation through prevention of the initial elongation step of protein synthesis. Omacetaxine interacts with A-site of the ribosome and disturbs the correct positioning of amino acid side chains of incoming aminoacyltRNAs (Figure 3). It acts on the first step of protein translation only and does not inhibit further steps of protein synthesis from mRNAs when the translation have already proceeded [25]. Probably, the site of homoharringtonine binding on 80S ribosomes overlaps or is the same as the acceptor site of the ribosome peptidyl transferase center [26, 27]. The detailed mechanism of homoharringtonine binding to ribosomes needs additional investigations elucidating details of this interaction. 
Table 1. Analytical determination of homoharringtonine and harringtonine.

\begin{tabular}{|c|c|c|c|c|}
\hline Method & Analytes & Matrix & Publ. & Ref. \\
\hline $\begin{array}{l}\text { MEEKC ( microemulsion } \\
\text { electrokinetic chromatography) } \\
\text { coupling with field-amplified } \\
\text { sample injection (FASI) }\end{array}$ & $\begin{array}{l}\text { HHT } \\
\text { and } 4 \text { other } \\
\text { isoquinoline } \\
\text { alkaloids }\end{array}$ & urine & 2009 & 2 \\
\hline $\begin{array}{l}\text { HPLC-electrospray tandem MS } \\
\text { (HPLC-MS/MS) }\end{array}$ & $\begin{array}{l}\text { HT } \\
\text { HHT } \\
\text { deoxy HT } \\
\text { iso HT } \\
\text { \& } 5 \text { other alkaloids }\end{array}$ & $\begin{array}{l}\text { C. harringtonia leaves - } \\
\text { various extracts }\end{array}$ & 2003 & 3 \\
\hline HPLC; NMR; MS & $\begin{array}{l}\text { HT } \\
\text { HHT } \\
\text { iso HT } \\
\text { ethyl HHT } \\
\end{array}$ & $\begin{array}{l}\text { pharmaceutical } \\
\text { preparations }\end{array}$ & 2000 & 4 \\
\hline HPLC (detection at $290 \mathrm{~nm}$ ) & HHT & serum & 1999 & 5 \\
\hline HPLC (detection at $288 \mathrm{~nm}$ ) & HHT & injection solutions & 1999 & 6 \\
\hline HPLC; MS & $\begin{array}{l}\text { HT } \\
\text { HHT } \\
\text { cephalotaxine }\end{array}$ & $\begin{array}{l}\text { C. harringtonia callus and } \\
\text { roots (methanol and } \\
\text { chloroform extract) }\end{array}$ & 1996 & 7 \\
\hline HPLC (detection at $280 \mathrm{~nm}$ ) & HHT & $\begin{array}{l}\text { urine, plasma and } \\
\text { cell homogenate }\end{array}$ & 1995 & 8 \\
\hline $\begin{array}{l}\text { Counter-current chromatography; } \\
\text { TLC; MS }\end{array}$ & $\begin{array}{l}\text { HT } \\
\text { HHT } \\
\text { iso HT }\end{array}$ & C. fortunii - a crude extract & 1992 & 9 \\
\hline HPLC (detection at $290 \mathrm{~nm}$ ) & $\begin{array}{l}\mathrm{HT} \\
\text { HHT } \\
\text { iso HT } \\
\text { cephalotaxine } \\
\end{array}$ & $\begin{array}{l}\text { Cephalotaxus bark } \\
\text { extracted } \\
\text { in aqueous NH3 solution }\end{array}$ & 1991 & 10 \\
\hline $\begin{array}{l}\text { HPLC with amperometric } \\
\text { detection; } \\
\text { IS - harringtonine }\end{array}$ & HHT & plasma, serum & 1989 & 11 \\
\hline RP-HPLC & $\mathrm{HT}$ & $\begin{array}{l}\text { tissue samples, extracted } \\
\text { by } 0.2 \mathrm{M} \mathrm{HCl} \text {; }\end{array}$ & 1989 & 12 \\
\hline $\begin{array}{l}\text { spectrophotometry } \\
\text { (detection at286 and } 282 \mathrm{~nm} \text { ) }\end{array}$ & $\mathrm{HT}$ & liposomes & 1984 & 13 \\
\hline $\begin{array}{l}\text { TLC; detection by Dragendorff's } \\
\text { reagent \& scanner }\end{array}$ & $\begin{array}{l}\text { HHT } \\
\text { (epimers) }\end{array}$ & natural homoharringtonine & 1984 & 14 \\
\hline HPLC (preparative) & $\begin{array}{l}\text { HT } \\
\text { and diastereo } \\
\text { isomers }\end{array}$ & & 1983 & 15 \\
\hline HPLC & $\begin{array}{l}\text { HT } \\
\text { HHT } \\
\end{array}$ & plasma, serum & 1982 & 16 \\
\hline GC-MS & $\begin{array}{l}\mathrm{HT} \\
\mathrm{HHT} \\
\end{array}$ & serum & 1982 & 17 \\
\hline
\end{tabular}

HHT - homoharringtonine; HT - harringtonine; NMR - nucleic magnetic resonance; IS - internal standard; GC - gas chromatography

It was shown for related harringtonine [28] that it may cause decrease in intracellular levels of centromere proteins. Possibly, this is caused by the inhibition of mRNA expression of corresponding genes, especially of CenpB and other centromere protein genes, as the expression of these genes is related to apoptosis induction by harringtonine. Additionally, it was shown that TGF-beta, TNF, FAS, p38MAPK and $\mathrm{p} 53$ apoptosis signaling pathways are activated during homoharringtonine-induced apoptosis in QGY-7703 cells [29]. When tested in myeloma cells, homoharringtonine significantly reduced Mcl-1 - an essential protein for myeloma cell survival [30]. Additionally, homoharringtonine causes dual downregulatiton of c-FLIP(L/S), protein characterized by its anti-apoptotic properties. Consequently, dual c-FLIP(L/S) downregulation sensitizes cells to induced apoptosis [31]. It is documented that apoptosis induced by homoharringtonine is mediated via both intrinsic and extrinsic apoptosis pathways [30].

Interesting results were obtained when a pro-apoptotic ligand from the TNF-alpha family -TNF-related apoptosis- 
<smiles>COC12CC3CCN(CCc4cc5c(cc4C3C1O)OCO5)C2</smiles><smiles>CC(=O)CC1(C(=O)OC(=O)c2c(Cl)cc(Cl)cc2Cl)CCCC(C)(C)O1</smiles><smiles></smiles><smiles>COC(=O)CC(O)(CCCC(C)(C)O)CC(=O)OC1C2CC34CCCN3CCc3cc5c(cc3C1C24)OCO5</smiles>

Figure 2. The semi-synthesis of enantiopure homoharringtonine according Robin J-P et al. [22]

inducing ligand (TRAIL) was applied to resistant cell lines together with homoharringtonine that demonstrated to be a very efficient enhancer of TRAIL-induced apoptosis. The application of very low quantities of homoharringtonine re- sulted in apoptosis induction. This was achieved through down regulation of the expression of the anti-apoptotic proteins Mcl-1 and cFLIP. Additionally, TRAIL-triggered activation of JNK and p38 kinases was observed [32].

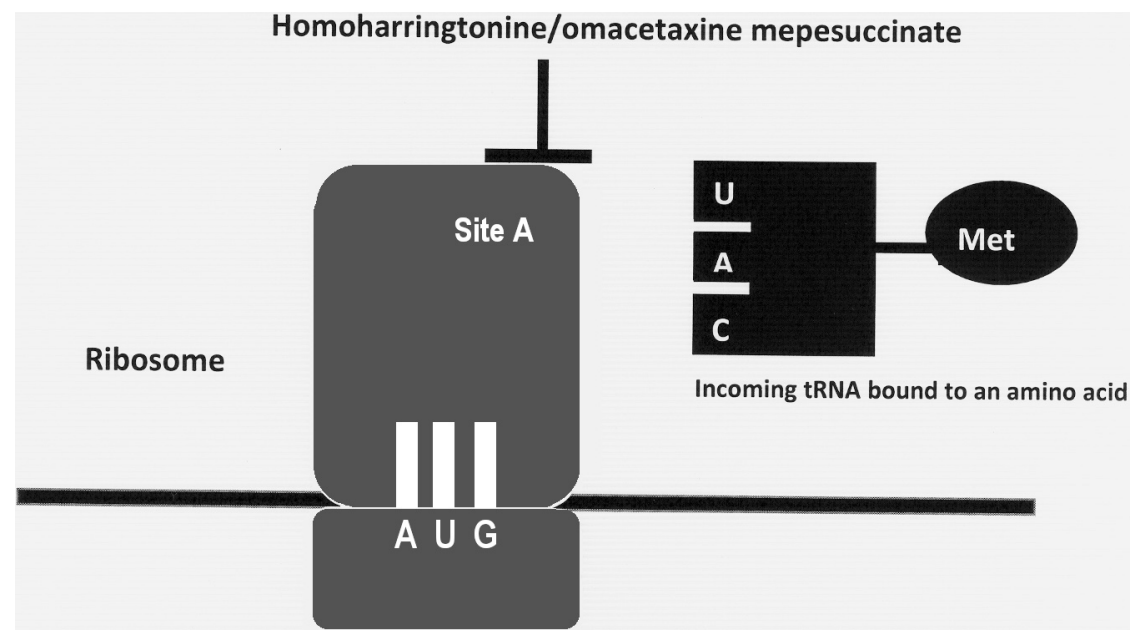

Figure 3. Homoharringtonine (omacetaxine mepesuccinate) mechanism of action 


\section{Sensitivity of tyrosine kinase inhibitors-resistant cells to omacetaxine}

The success of Omacetaxine mepesuccinate in patients with chronic myeloid leukemia (with the Philadelphia chromosome positive stem cells; CML) is based on the fact that its mechanism of action differs from that of tyrosine kinase inhibitors competing with ATP for binding site at ABL of the BCR-ABL fusion gene. In general, while Omacetaxine mepesuccinate inhibits the synthesis of BCR-ABL tyrosine kinase. On the other hand, clinically used TKIs compete with already synthesized BCR-ABL tyrosine kinase thus inhibiting its action. The product of $B C R-A B L$ gene is active tyrosine kinase promoting leukemogenesis via downstream signaling. The result of the TKIs action is inhibition of the BCR-ABL-produced tyrosine kinase. This leads to the block of cytokine-independent cell cycle unresponsive to apoptotic signaling $[33,34]$.

Omacetaxine mepesuccinate, on the other hand, does not bind to BCR-ABL and its action is not affected by the mutation of kinase domain erasing from CML chemotherapy by TKIs [35]. This drug was shown to be effective even in patients with a T315I ABL mutation that is generally a poor prognosis population [36]. Additionally, it was shown to block synthesis of other proteins that help to stabilize the ABL protein, i.e. heat shock protein 90 (HSP90) [37]. As Omacetaxine mepesuccinate initiates a rapid disappearance of T315I-mutated TKIs-resistant transcripts in the half of CML patients. The exact mechanism of this process is not elucidated yet but it allows for re-introduction or 'rechallenge' of TKIs therapy in previously TKIs resistant chronic-phase CML patients [38].

\section{Pharmacokinetics of Omacetaxine mepesuccinate}

Pharmacokinetic parameters are essential for administration of any substance employed as a therapeutic agent. Early in homoharringtonine studies, the only metabolite of this substance in human (and murine) plasma was identified as 2'-hydroxy-2'-(alpha-acetic acid)-6'-hydroxy-6'-methylheptanoyl cephalotaxine [19]. The metabolism proceeds due to plasma esterases' [19]. Urine excretion represented $29 \%$ of homoharringtonine and $20 \%$ as its metabolite 24 hours after homoharringtonine administration. Later, 72 hours after homoharringtonine administration, urinary elimination of this substance increased to $40 \%$ of the dose, while only $22 \%$ metabolized [19]. Approximately $14 \%$ of homoharringtonine are excreted through biliary tract [39].

\section{Therapeutic use of Omacetaxine mepesuccinate as replace- ment of tyrosine-kinase inhibitors in resistant leukemia patients}

Omacetaxine mepesuccinate use benefits CML patients possessing the $B C R-A B L$ oncogene. Cytogenetic diagnosis of CML is based on the determination of Philadelphia chro- mosome $(\mathrm{Ph})$ resulting in formation of $B C R-A B L . B C R-A B L$ oncogene, the production of which is directly related to the presence of $\mathrm{Ph}$ chromosome, deregulates activity of tyrosine kinase. This leads to generation of different BCR-ABL proteins and, consequently, to the CML advancement [40]. Many reports on the use of the natural alkaloid homoharringtonine and the same molecule of the semisynthetic commercial product Omacetaxine mepesuccinate in CML appeared in scientific literature from 1990. Only the some of the latest studies will be mentioned as the use of this substance in CML therapy got much improved, justified and explained, and directed to the CML patients resistant to TKIs during the years.

The use of Omacetaxine mepesuccinate represents a significant addition to the progressive CML management after multi-TKI resistance develops - 'third-line management of CML' using non-TKI drugs. Additionally, Omacetaxine mepesuccinate (or ponatinib) should be used in patients with T315I mutation at any CML phase [41]. Results of the analysis of 24 months follow-up of patients on Omacetaxine mepesuccinate shown that a major cytogenetic response was registered in $18 \%$ of patients in chronic phase CML (median duration 12.5 months). The median overall survival was 40.3 months (23.8 months in patients not responsive to the therapy) [42]. A major hematologic response, but not a major cytogenetic response, was registered in $14 \%$ of patients in acute phase CML with median duration 4.7 months (3.6 months in patients not responsive to the therapy with Omacetaxine mepesuccinate). All the data of the analysis of this 24 months follow-up indicate that the long-term use of Omacetaxine mepesuccinate is possible and that it significantly benefits some patients [41]. Similar conclusions were drawn by other authors confirming that Omacetaxine mepesuccinate is beneficial even for some poor prognosis TKI-resistant CML patients [i.e. 43-45].

Results of the meta-analysis of 21 Chinese studies were published this year [46]. The included studies analyzed information on 1310 patients who were given Omacetaxine mepesuccinate with several anticancer agents, i.e. daunorubicin, idarubicin, cytarabine, aclacinomycin, mitoxantrone or granulocyte colony-stimulating factor. Observed rate of complete remissions was $65.2 \%$ in regimens involving Omacetaxine mepesuccinate. This was lower compared to complete remissions in regiments without this drug in randomized trials $-69.1 \%$. The achieved complete remission in retrospective studies were achieved in $62.8 \%$ of treated patients [46]. A complete remission rate was significantly decreased in elderly patients: only $47.5 \%$ in elderly patients compared to $65.2 \%$ in the mixed age patients' cohorts [46]. This may indicate a higher benefit from the use of Omacetaxine mepesuccinate in younger patients.

Omacetaxine mepesuccinate is being used in combinations with low dose cytarabine [47], IFN [48] or both [49] and also with imatinib [50]. This was recently well summarized in a published review [51]. 


\section{Adverse side-effects of Omacetaxine therapy}

It was clearly demonstrated that Omacetaxine is active and has an acceptable safety profile in pretreated patients with advanced CML, irrespective of mutational status through promotion of apoptosis via inhibition of oncoproteins production [52]. The addition of Omacetaxine to the therapeutic armamentarium of chronic myeloid leukemia was significantly improved, especially for patients resistant to both first- and second-generation tyrosine-kinase inhibitors with developed BCR-ABL kinase domain mutations, against which TKIs have extremely low cross-activity [53]. Accumulated experience shows that a treatment of leukemia patients with Omacetaxine is accompanied only with generally mild non-hematologic toxicity, possibly with higher prevalence in elderly patients [54].

Data were published on the ability of homoharringtonine (a commercial product Omacetaxine mepesuccinate) to induce changes in the gastrointestinal tract, i.e. diarrhea and nausea/ vomiting [55]. Reasons behind these side effects were not elucidated. Recently, the results of the study [55] indicated that homoharringtonine changes the epithelial permeability of intestinal Caco-2 cell monolayers through reduction of the trans-epithelial electrical resistance of these cells in a time- and dose-dependent manner via modulation of the expression and localization of protein claudin isoforms. However, the changes in the epithelial permeability were reversible and free of cytotoxicity [55].

The dose-related myelosuppression represents a principal adverse side effect of omacetaxine mepesuccinate therapy. The granulocytopenia was observed in $27 \%$ - 39\% of patients and $13 \%$ $-25 \%$ of patients suffered from thrombocytopenia $[56,57]$.

The following non-hematologic adverse effects on omacetaxine mepesuccinate are the most prominent: fatigue, diarrhea, pyrexia, nausea, headache, asthenia, anorexia, hyperglycemia, injection-site erythema and tachycardia or chest pain [57-60]. The non-hematological adverse effects are not common [61]. The important fact is that results of safety analysis of the use of subcutaneous omacetaxine mepesuccinate in tyrosine kinase inhibitors-resistant patients confirmed an acceptable safety profile in all CML patients with the concern remaining regarding the potential adverse effects resulting from long-term use of this drug [61].

More recent studies found the occurrence of grade $3 / 4$ hematologic toxicities to be 54\% [62] or 76\% [63] for thrombocytopenia, 48\% [62] or 44\% [63] for neutropenia and 33\% [62] or 39\% [63] anemia, respectively. Observed non-hematological effects were usually of grade 1 or 2 . They included diarrhea (44\% [62] or $40 \%$ [63]), nausea (30\% [62] or $34 \%$ [63]), fatigue $(24 \%)$, pyrexia $(20 \%)$, headache $(20 \%)$, asthenia $(20 \%)$ and infection (42\%) [62]. These adverse effects of Omacetaxine mepesuccinate therapy in CML patients were not significant enough to prevent granting of an accelerated approval of the drug (Synribo; Teva Pharmaceuticals USA, Inc., North Wales, PA, http://www.tevausa.com) for CML with resistance and/or intolerance to two or more tyrosine kinase inhibitors (TKIs) in October 2012 by the U.S. Food and Drug Administration
(FDA). The accelerated approval was granted based on the therapeutic "activity and a favorable benefit-to-risk profile for the studied population of adult patients" [61]. It was approved by FDA for the use in such patients in 2014 [64] as it has demonstrated activity and a favorable benefit-to-risk profile in the studied populations of adult patients with both phases CML.

\section{Omacetaxine mepesuccinate in non-CML patients}

Omacetaxine mepesuccinate approval by FDA for the use in CML refractory to TKIs indicate where this drug is the most successful. However, other indication of the use of omacetaxine mepesuccinate were investigated. These reports are just few but may be important for future development. The omacetaxine mepesuccinate activity in treatment of acute myeloid leukemia was summarized by a meta-analysis in 2015 [46] with the conclusion that this drug may serve as an active agent in the management of acute myeloid leukemia.

In China, this substance is used not only for the therapy of CML and acute myeloid leukemia (AML) but also in patients with myelodysplastic syndrome (MDS). Eleven homoharringtonine-based therapy clinical trials were summarized [64] with complete remissions achieved ranging from 71 to $86 \%$ of patients and with 3 -years complete survival ranging from 45 to $55 \%$. Complete remissions achieved in patients with MDS ranged from 47 to 58\% [64]. A phase II open-label study of the intravenous administration of homoharringtonine in the MDS therapy of 9 patients performed in the USA [65] reported omacetaxine mepesuccinate to produce complete remission in one patient. The other eight enrolled-in-the-trial patients did not respond to this therapy. Consequently, some patients may benefit from inclusion of omacetaxine mepesuccinate into their therapeutic regime but more clarifications and clinical trials are necessary for full understanding of various aspects of therapeutic activity of this substance.

Based on available literature, it seems safe to conclude that omacetaxine mepesuccinate will be evaluated extensively on its usefulness in patients with AML and MDS in near future.

\section{Historical note on the development of Omacetaxine mepesuccinate}

Development of this drug is an interesting example of the influence of the geographical location of the source of the active natural ingredient homoharringtonine on the drug development. As the source of the alkaloid homoharringtonine is endemic to eastern Asia [1]. Consequently, the significant attention to the biologically active compound was paid in China. Later, when the issue of limited source of homoharringtonine was overcome by preparing it semisynthetically from another more available alkaloid cephalotaxine under the name Omacetaxine mepesuccinate [i.e. 22], clinical investigations were no longer limited by availability of the therapeutic substance. Twenty five clinical trials were performed according to PubMed 
during the last 10 years. Out of these trials, 17 were performed in China and 7 in the USA. Only one clinical trial was performed in France in 2006 at early stages of the omacetaxine mepesuccinate development [18]. However, omacetaxine mepesuccinate clinical trials shifted to the USA during the last five years when 8 of clinical trials were performed in China, 6 in the USA and none in another country (PubMed: http://www.ncbi.nlm.nih. gov/pubmed). It is possible that with the FDA approval, some clinical trials would be performed outside of the USA and China or some trial would be performed in collaboration.

\section{Conclusion}

Approval of omacetaxine mepesuccinate for the use in CML therapy in 2014 brought new options to CML patients. As it targets protein translation, this drug possesses a new mechanism of action. However, additional information on omacetaxine mepesuccinate and its pharmacokinetic and pharmacodynamic behavior is still needed as better elucidation of properties and biological activities of this drug will help in its optimal use. Also, improved understanding of the omacetaxine mepesuccinate action in various patients' populations (age, gender, stage of the disease) need to be elucidated and understand together with the most successful combination of omacetaxine mepesuccinate with other anticancer agents, including TKIs. The primary success of omacetaxine mepesuccinate in CML patients resistant to multiple TKIs may be broadened by finding alternatives for its inclusion in other cancers therapies or finding more efficient combinations for therapy of present indications. However, at the present time, the use of omacetaxine mepesuccinate and investigation of its benefits for patients concentrates on CML.

Acknowledgements: This work was supported by VEGA 2/0080/15 and VEGA 02/0092/16 grants.

\section{References}

[1] THE PLANT LIST (2013). Version 1.1. Published on the Internet; http: //www.theplantlist.org; http: //www.theplantlist. org/tpl1.1/search?q=Cephalotaxus (accessed 14 February 2016).

[2] YU LS, XU XQ, HUANG L, LIN JM, CHEN GN. Separation and detection of isoquinoline alkaloids using MEEKC coupled with field-amplified sample injection induced by ACN. Electrophoresis, 2009; 30: 661-667. http://dx.doi.org/10.1002/ elps.200800555

[3] CHOI YH, YOO KP, KIM JW. HPLC-electrospray ionizationMS-MS analysis of Cephalotaxus harringtonia leaves and enhancement of the extraction efficiency of alkaloids therein by SFE. J Chromatogr Sci. 2003; 41: 67-72. http://dx.doi. org/10.1093/chromsci/41.2.67

[4] HE JY, CHEUNG AP, WANG E, STRUBLE E, FANG K et al. Stability-indicating LC assay of and impurity identification in homoharringtonine samples. J Pharm Biomed Anal. 2000; 22: 541-554. http://dx.doi.org/10.1016/S0731-7085(99)00314-3
[5] YANG M, YANG CZ, MA JG, BIAN SG, XUE, YP. Determination of the content of homoharringtonine in serum by HPLC. Yaowu Fenxi Zazhi 1999; 19: 147-149.

[6] GAO SY, LIN LJ. Determination of homoharringtonine contained in homoharringtonine injection by HPLC. Yaowu Fenxi Zazhi 1999; 19: 103-105.

[7] WICKREMESINHE ERM, ARTECA RN. HPLC separation of cephalotaxine, harringtonine and homoharringtonine from callus and root cultures of Cephalotaxus Harringtonia. J Liq Chromatogr \& Related Technol. 1996; 19: 889-897. http:// dx.doi.org/10.1080/10826079608001919

[8] SHAO H. Determination of homoharringtonine in urine, blood and cell homogenate by high-performance liquid chromatography. Yaowu Fenxi Zazhi 1995; 15: 44.

[9] CAI D-G, GU M-J, ZHU G-P, ZHANG J-D, ZHANG, T-Y et al. Semi-preparative separation of alkaloids from Cephalotaxus fortunii Hook. f. by high-speed counter-current chromatography. J Liq Chromatogr \& Related Technol. 1992; 15: : 2873-2881. http://dx.doi.org/10.1080/10826079208016354

[10] WANG M, ZHANG L, CHEN Y. HPLC separation and determination of alkaloids in cephalotaxus plant. Yaowu Fenxi Zazhi, 1991; 11: 333-336.

[11] CHAN Y-PM, LEE F-W, SIU T-SS. Quantitation of homoharringtonine in plasma by high-performance liquid chromatography with amperometric detection. J Chromatogr: Biomed Appl. 1989; 88 (J Chromatogr. 496): 155-166.

[12] WU H, ZHOU X, WENG G, CHEN D. Quantitation of liposome-encapsulated harringtonine and of harringtonine in rat tissues by HPLC. Zhongguo Yaoke Daxue Xuebao 1989; 2: 77-81.

[13] TANG L, WENG G. Application of orthogonal-function spectrophotometry to determination of harringtonine in liposomes. Yaowu Fenxi Zazhi 1984; 4: 197-200.

[14] ZHOU Z, ZHANG G. Analysis of Cephalotaxus [Chinese Plum-Yew] alkaloids. II. Thin-layer chromatographic separation and determination of two epimers of partially synthetic homoharringtonine. Yaowu Fenxi Zazhi 1984; 4: 70-74.

[15] HUANG L, FANG Q, CHENG J, QIANG Z. Separation, and identification, of the diastereoisomers of harringtonine from epi-harringtonine by preparative high-performance liquid chromatography. Fenxi huàxué 1983; 11: 158-159.

[16] JUI H, ROBOZ J. Quantitation of harringtonine and homoharringtonine in serum by high-performance liquid chromatography. J Chromatogr: Biomed Appl. 1982; 22 ((J. Chromatogr. 233)): 203-211.

[17] ROBOZ J, GREAVES J, JUI H, HOLLAND JF. Quantification of homoharringtonine and harringtonine in serum by chemical-ionization mass spectrometry. Biomed Mass Spectrometry 1982; 9: 510-514. http://dx.doi.org/10.1002/ bms.1200091203

[18] LEVY V, ZOHAR S, BARDIN C, VEKHOFF A, CHAOUI $\mathrm{D}$ et al. A phase I dose-finding and pharmacokinetic study of subcutaneous semisynthetic homoharringtonine (ssHHT) in patients with advanced acute myeloid leukeamia. Br J Cancer 2006; 95: 253-259. http://dx.doi.org/10.1038/sj.bjc.6603265

[19] NI D, HO DH, VIJJESWARAPU M, FELIX E, RHEA PR et al. Metabolism of homoharringtonine, a cytotoxic component 
of the evergreen plant Cephalotaxus harringtonia. J Exp Ther Oncol 2003; 3: 47-52. http://dx.doi.org/10.1046/j.1359-4117 .2003.01066.X

[20] KANTARJIAN H, O'BRIEN S, CORTES J. Homoharringtonine/Omacetaxine: The little drug that could. The ASCO Post 2013, Volume 4, Issue 6;

http: //www.ascopost.com/issues/april-15,-2013/homoharringtonineomacetaxine-the-little-drug- that-could.aspx (accessed on 28 November 2015).

[21] HIRANUMA S, HUDLICKY T. Synthesis of homoharringtonine and its derivative by partial esterification of cephalotaxine. Tetrahedron Lett. 1982; 23: 3431-3434 http:// dx.doi.org/10.1016/S0040-4039(00)87634-0

[22] ROBIN J-P, DHAL R, DUJARDIN G, GIRODIER L, MEYELLEC $L$ et al. The first semi-synthesis of enantiopure homoharringtonine via anhydrohomoharringtonine from a preformed chiral acyl moiety. Tetrahedron Lett. 1999; 40: $2931-$ 2934. http://dx.doi.org/10.1016/S0040-4039(99)00327-5

[23] ZHANG ZW, ZHANG XF, FENG J, YANG YH, WANG CC et al. Formal synthesis of cephalotaxine. J Org Chem. 2013; 78: 786-790. http://dx.doi.org/10.1021/jo302608a

[24] ZHANG QW, XIANG K, TU YQ, ZHANG SY, ZHANG XM ET AL. Formal synthesis of (-)-cephalotaxine based on a tandem hydroamination/semipinacol rearrangement reaction. Chem Asian J. 2012; 7: 894-898. http://dx.doi. org/10.1002/asia.201101029

[25] WETZLER M, SEGAL D. Omacetaxine as an Anticancer Therapeutic: What is Old is New Again. Current Pharmaceutical Design 2011; 17: 59-64. http://dx.doi. org/10.2174/138161211795049778

[26] TUJEBAJEVA RM, GRAIFER DM, KARPOVA GG, AJTKHOZHINA NA. Alkaloid homoharringtonine inhibits polypeptide chain elongation on human ribosomes on the step of peptide bond formation. FEBS Lett. 1989; 257: 254-256. http://dx.doi.org/10.1016/0014-5793(89)81546-7

[27] TUJEBAJEVA RM, GRAIFER DM, MATASOVA NB, FEDOROVA OS, ODINTSOV VB et al. Selective inhibition of the polypeptide chain elongation in eukaryotic cells. Biochim Biophys Acta 1992; 1129: 177-182. http://dx.doi. org/10.1016/0167-4781(92)90484-H

[28] LIANG SH, PENG A, WANG YC, ZHANG HX, LI YZ et al. Effects of anti-leukemia drug Harringtonine on the levels of centromere proteins and gene expression of CenpB in L1210 cells. Yi Chuan Xue Bao 2003; 30: 521-527.

[29] JIN W, QU LF, CHEN Q, CHANG XZ, WU J et al. Gene expression pattern in apoptotic QGY-7703 cells induced by homoharringtonine. Acta Pharmacol Sin. 2007; 28: 859-868. http://dx.doi.org/10.1111/j.1745-7254.2007.00569.x

[30] KURODA J, KAMITSUJI Y, KIMURA S, ASHIHARA E, KAWATA E et al. Anti-myeloma effect of homoharringtonine with concomitant targeting of the myeloma-promoting molecules, Mcl-1, XIAP, and beta-catenin. Int J Hematol. 2008 Jun; 87: 507-515. http://dx.doi.org/10.1007/s12185-008-0081-8

[31] MCLORNAN D, HAY J, MCLAUGHLIN K, HOLOHAN C, BURNETT AK et al. Prognostic and therapeutic relevance of c-FLIP in acute myeloid leukaemia. Br J Haematol. 2013; 160: 188-198. http://dx.doi.org/10.1111/bjh.12108
[32] BERANOVA L, POMBINHO AR, SPEGAROVA J, KOC M, KLANOVA $\mathrm{M}$ et al. The plant alkaloid and anti-leukemia drug homoharringtonine sensitizes resistant human colorectal carcinoma cells to TRAIL-induced apoptosis via multiple mechanisms. Apoptosis. 2013; 18: 739-750. http://dx.doi. org/10.1007/s10495-013-0823-9

[33] JABBOUR E, KANTARJIAN H. Chronic myeloid leukemia: Update on diagnosis, monitoring and management. Am J Hematol. 012; 87: 1037-1045. http://dx.doi.org/10.1017/ cbo9780511781926.004

[34] NARAYANAN V, GUTMAN JA, POLLYEA DA, JIMENO A. Omacetaxine mepesuccinate for the treatment of chronic myeloid leukemia. Drugs Today (Barc). 2013; 49: 447-456. http://dx.doi.org/10.1358/dot.2013.49.7.1980495

[35] CHEN R, GANDHI V, PLUNKETT W. A sequential blockade strategy for the design of combination therapies to overcome oncogene addiction in chronic myelogenous leukemia. Cancer Res. 2006; 66: 10959-10956. http://dx.doi.org/10.1158/00085472.CAN-06-1216

[36] HEIBLIG M, SOBH M, NICOLINI FE. Subcutaneous omacetaxine mepesuccinate in patients with chronic myeloid leukemia in tyrosine kinase inhibitor-resistant patients: review and perspectives. Leuk Res. 2014; 38: 1145-1153. http://dx.doi. org/10.1016/j.leukres.2014.05.007

[37] OKABE S, TAUCHI T, TANAKA Y, KATAGIRI S, KITAHARA T et al. Activity of omacetaxine mepesuccinate against ponatinib-resistant BCR-ABL-positive cells. Blood. 2013; 122: 3086-3088. http://dx.doi.org/10.1182/blood-2013-04$\underline{494773}$

[38] NICOLINI FE, CHOMEL JC, ROY L, LEGROS L, CHABANE $\mathrm{K}$ et al. The durable clearance of the T315I BCR-ABL mutated clone in chronic phase chronic myelogenous leukemia patients on omacetaxine allows tyrosine kinase inhibitor rechallenge. Clin Lymphoma Myeloma Leuk. 2010; 10: 394-399. http:// dx.doi.org/10.3816/CLML.2010.n.073

[39] LU K, SAVARAJ N, FEUN LG, GUO ZG, UMSAWASDI T et al. Pharmacokinetics of homoharringtonine in dogs. Cancer Chemother Pharmacol 1988; 21: 139-142. http://dx.doi. org $/ 10.1007 / \mathrm{bf} 00257360$

[40] LI S, ILARIA RL JR, MILLION RP, DALEY GQ, VAN ETTEN RA. The P190, P210, and P230 forms of the BCR/ABL oncogene induce a similar chronic myeloid leukemia-like syndrome in mice but have different lymphoid leukemogenic activity. J Exp Med. 1999; 189: 1399-1412. http://dx.doi. org/10.1084/jem.189.9.1399

[41] HAZNEDAROGLU IC. Drug Therapy in the Progressed CML Patient with multi-TKI Failure. Mediterr J Hematol Infect Dis. 2015; 7: e2015014. eCollection 2015.

[42] CORTES JE, KANTARJIAN HM, REA D, WETZLER M, LIPTON JH et al. Final analysis of the efficacy and safety of omacetaxine mepesuccinate in patients with chronic- or accelerated-phase chronic myeloid leukemia: Results with 24 months of follow-up. Cancer. 2015; 121: 1637-1644. http:// dx.doi.org/10.1002/cncr.29240

[43] HEIBLIG M, SOBH M, NICOLINI FE. Subcutaneous omacetaxine mepesuccinate in patients with chronic myeloid leukemia in tyrosine kinase inhibitor-resistant patients: review 
and perspectives. Leuk Res. 2014; 38: 1145-1153. http://dx.doi. org/10.1016/j.leukres.2014.05.007

[44] AL USTWANI O, GRIFFITHS EA, WANG ES, WETZLER M. Omacetaxine mepesuccinate in chronic myeloid leukemia. Expert Opin Pharmacother. 2014; 15: 2397-2405. http:// dx.doi.org/10.1517/14656566.2014.964642

[45] DAMLAJ M, ASSOULINE S. Is there a role for omacetaxine in the management of chronic myelogenous leukemia in the era of the tyrosine kinase inhibitors? Leuk Lymphoma. 2015; 56: 6-7. http://dx.doi.org/10.3109/10428194.2014.918972

[46] KANTARJIAN H, O'BRIEN S, JABBOUR E, BARNES G, PATHAK A et al. Effectiveness of homoharringtonine (omacetaxine mepesuccinate) for treatment of acute myeloid leukemia: a meta-analysis of Chinese studies. Clin Lymphoma Myeloma Leuk. 2015; 15: 13-21. http://dx.doi.org/10.1016/j. clml.2014.09.011

[47] STONE RM, DONOHUE KA, STOCK W, HARS V, LINKER CA et al. A phase II study of continuous infusion homoharringtonine and cytarabine in newly diagnosed patients with chronic myeloid leukemia: CALGB study 19804. Cancer Chemother Pharmacol 2009; 63: 859-864. http://dx.doi. org/10.1007/s00280-008-0805-8

[48] KANTARJIAN HM, TALPAZ M, SMITH TL, CORTEZ J, GILES FJ et al. Homoharringtonine and low-dose cytarabine in the management of late chronic-phase chronic myelogenous leukemia. J Clin Oncol 2000; 18: 3513-3521.

[49] O'BRIEN S, GILES F, TALPAZ M, CORTES J, RIOS MB et al. Results of triple therapy with interferon-alpha, cytarabine, and homoharringtonine, and the impact of adding imatinib to the treatment sequence in patients with Philadelphia chromosome-positive chronic myelogenous leukemia in early chronic phase. Cancer 2003; 98: 888-893. http://dx.doi. org/10.1002/cncr.11620

[50] MARIN D, KAEDA JS, ANDREASSON C, SAUNDERS SM, BUA $M$ et al. Phase I/II trial of adding semisynthetic homoharringtonine in chronic myeloid leukemia patients who have achieved partial or complete cytogenetic response on imatinib. Cancer 2005; 103: 1850-1855. http://dx.doi. org/10.1002/cncr.20975

[51] GANDHI V, PLUNKETT W, CORTES J. Omacetaxine: A Protein Translation Inhibitor for Treatment of Chronic Myelogenous Leukemia. Clin Cancer Res 2014; 20: 1735-1740. http://dx.doi.org/10.1158/1078-0432.CCR-13-1283

[52] KHOURY HJ, CORTES J, BACCARANI M, WETZLER M, MASSZI T et al. Omacetaxine mepesuccinate in patients with advanced chronic myeloid leukemia with resistance or intolerance to tyrosine kinase inhibitors. Leuk Lymphoma. 2015; 56: 120-127. http://dx.doi.org/10.3109/10428194.2014.889826

[53] VISANI G, ISIDORI A. Resistant chronic myeloid leukemia beyond tyrosine-kinase inhibitor therapy: which role for omacetaxine? Expert Opin Pharmacother. 2014; 15: 1-3. http:// dx.doi.org/10.1517/14656566.2014.850491

[54] KIM TD, FRICK M, LE COUTRE P. Omacetaxine mepesuccinate for the treatment of leukemia. Expert Opin Pharmacother. 2011; 12: 2381-2392. http://dx.doi.org/10.15 $\underline{17 / 14656566.2011 .613378}$
[54] WATARI A, HASHEGAWA M, YAGI K, KONDOH M. Homoharringtonine increases intestinal epithelial permeability by modulating specific claudin isoforms in Caco-2 cell monolayers. Eur J Pharm Biopharm. 2015; 89: 232-238. http://dx.doi.org/10.1016/j.ejpb.2014.12.012

[55] O'BRIEN S, KANTARJIAN H, KEATING M, BERAN M, KOLLER $\mathrm{C}$ et al. Homoharringtonine therapy induces responses in patients with chronic myelogenous leukemia in late chronic phase. Blood. 1995; 86: 3322-3326.

[56] O'BRIEN S, KANTARJIAN H, KOLLER C, FELDMAN E, BERAN M. et al. Sequential homoharringtonine and interferon-alpha in the treatment of early chronic phase chronic myelogenous leukemia. Blood. 1999; 93: 4149-4153.

[57] QUINTAS-CARDAMA A, KANTARJIAN H, GARCIAMANERO G, O'BRIEN S, FADERL $S$ et al. Phase I/II study of subcutaneous homoharringtonine in patients with chronic myeloid leukemia who have failed prior therapy. Cancer. 2007; 109: 248-255. http://dx.doi.org/10.1002/ cncr.22398

[58] SYLVESTER RK, LOBELL M, OGDEN W, STEWART JA. Homoharringtonine-induced hyperglycemia. J Clin Oncol. 1989; 7: 392-395.

[59] ALVANDI F, KWITKOWSKI VE, KO CW, ROTHMANN MD, RICCI $S$ et al. U.S. Food and Drug Administration approval summary: omacetaxine mepesuccinate as treatment for chronic myeloid leukemia. Oncologist. 2014; 19: 94-99. http://dx.doi.org/10.1634/theoncologist.2013-0077

[60] WETZLER M, KANTARJIAN H, NICOLINI FE, LIPTON JH, AKARD LP et al. Pooled safety analysis of omacetaxine mepesuccinate in patients with chronic myeloid leukemia (CML) resistant to tyrosine-kinase inhibitors (TKIs) J Clin Oncol. 2012; 30(Suppl) Abstr 6604.

[61] CORTES J, DIGUMARTI R, PARIKH PM, WETZLER M, LIPTON JH et al. Phase 2 study of subcutaneous omacetaxine mepesuccinate for chronic-phase chronic myeloid leukemia patients resistant to or intolerant of tyrosine kinase inhibitors. Am J Hematol. 2013; 88: 350-354. http://dx.doi.org/10.1002/ ajh. 23408

[62] CORTES J, LIPTON JH, REA D, DIGUMARTI R, CHUAH $\mathrm{C}$ et al. Phase 2 study of subcutaneous omacetaxine mepesuccinate after TKI failure in patients with chronic-phase CML with T315I mutation. Blood. 2012; 120: 2573-2580. http:// dx.doi.org/10.1182/blood-2012-03-415307

[63] U.S. Food and Drug Administration approval summary: omacetaxine mepesuccinate as treatment for chronic myeloid leukemia. Oncologist. 2014; 19: 94-99. http://dx.doi. org/10.1634/theoncologist.2013-0077

[64] LU S, WANG J. Homoharringtonine and omacetaxine for myeloid hematological malignancies. J Hematol Oncol. 2014; 7: 2. http://dx.doi.org/10.1186/1756-8722-7-2

[65] DAVER N, VEGA-RUIZ A, KANTARJIAN HM, ESTROV Z, FERRAJOLI A et al. A phase II open-label study of the intravenous administration of homoharringtonine in the treatment of myelodysplastic syndrome. Eur J Cancer Care (Engl) 2013; 22: 605-611. http://dx.doi.org/10.1111/ $\underline{\text { ecc. } 12065}$ 